\title{
UNCONSTITUTIONAL LEGISLATIVE SOLUTIONS ENSHRINED BY THE CIVIL PROCEDURE CODE
}

DOI: $10.47743 /$ rdc-2017-2-0004

Tudorel TOADER

ttoader@uaic.ro

Marieta SAFTA ${ }^{2}$

marietasafta@yahoo.com

\section{Abstract}

The study continues the presentation of the constitutional contentious court jurisprudence evolution, from determining the unconstitutionality of the legal norm to determining the unconstitutionality of the legal solution promoted by that norm, with punctual reference to the civil procedural law domain.

Keywords: jurisprudence; Constitution; constitutionality control; Civil Procedure Code; fundamental rights and freedoms

\section{The legislative solution which assigns to the courts the competence to carry out constitutional control it is unconstitutional. The court has the competence to apply the Constitution directly only in the hypothesis and terms established by the decision setting unconstitutionality given by the Constitutional Court}

The object of constitutionality control, as it has been formulated, is represented by the provisions of the Law on the approval of the Government Emergency Ordinance no. 95/2016 for the extension of some deadlines, as well as for the set out of some measures necessary to prepare for applying some provisions of the Law no. 134/2010 on the Civil Procedure Code, with the following content:

\footnotetext{
${ }^{1}$ Professor, PhD, Rector of "Al.I. Cuza" University of lași, Judge at the Constitutional Court of Romania (October 2006-July 2016), Minister of Justice.

2 Associate Professor, PhD, Faculty of Law of "Titu Maiorescu" University of Bucharest, First assistantmagistrate at the Constitutional Court of Romania (detached), Secretary of State at the Ministry of Justice.
} 
"Article I - It is approved the Government Emergency Ordinance no. 95 of December 8, 2016 for the extension of certain deadlines, as well as for the set out of some measures necessary for certain provisions preparation for implementation from the Law no. 134/2010 on the Civil Procedure Code, published in the Official Journal of Romania, Part 1, no. 1009 of December 15, 2016.

Article II - Law no. 134/2004 on the Civil Procedure Code, republished in the Official Journal of Romania, Part I, no. 247 of April 10, 2015, as amended and supplemented, shall be amended and completed as follows:

1. In Article 509 para. (1), after point 11, four new points are introduced, paragraphs 12-15, with the following content:

"12. when, after the delivery of the final judgment, the Constitutional Court adopts a decision by which are declared unconstitutional the legal provisions on which the final judgment was based, or whose considerations and/or provision are contrary to the final judgment;

13. the judgment is pronounced with infringement of the constitutional provisions, even though the issue of public order has not been invoked before the courts;

14. the judgment is pronounced in non-compliance with the provisions of the Constitutional Court's decisions, as well as of their considerations;

13. when the judgment is unlawful delivering sanctions on the basis of some legal provisions which were not into force at the time when the juridical report brought before aroused".

2. Article 509 para. (2) is amended and will have the following content:

"(2) For the revision reasons provided in para. (1) point 3, but only in the case of the judge, point 4, points 7-15 shall be subject to review and judgments which don't speak about the merits".

3. In Article 511, after para. (3), two new paragraphs $\left(3^{1}\right)$ and $\left(3^{2}\right)$ are introduced, with the following content:

" $\left(3^{1}\right)$ For the reasons set out in Article 509 (1) points 13-15, the term is of 12 months from the date of the final judgment.

$\left(3^{2}\right)$ For the reasons provided by Article 509 (1) point 12, the term is of 12 months from the publication in the Official Journal of Romania, Part I, of the Constitutional Court decisions».

Article III - in the situations provided by Article 51 para. $\left(3^{1}\right)$ and $\left(3^{2}\right)$ of the Law no. 134/2010 on the Civil Procedure Code, republished, as subsequently amended and supplemented, including those brought by this law, in which the judgment or the decision of the Constitutional Court, as the case may be, is prior to the entry into force of this law, the term is of 12 months from the date when this law enters into force".

Having regard to Article II point 1 of the Law [with reference to Article 509 para. (1) point 13 of the Civil Procedure Code], the Court held that, in its case-law, the court has the power to apply directly the Constitution only in the hypothesis and terms 
established by the decision setting unconstitutionality held by the Constitutional Court [see, with regard to the direct application of the Constitution, Decision no. 186 of November 18, 1999, published in the Official Journal of Romania, Part I, no. 213 of May 16, 2000, Decision no. 774 of November 10, 2015, published in the Official Journal of Romania, Part I, no. 8 of January 6, 2016, or Decision no. 895 of December 17, 2015, published in the Official Journal of Romania, Part I, no. 84 of February 4, 2016, Decision no. 24 of January 20, 2016, published in the Official Journal of Romania, Part I, no. 276 of April 12, 2016, paragraph 34, or Decision no. 794 of December 15, 2016, published in the The Official Journal of Romania, Part I, no. 1029 of December 21, 2016, paragraph 37]. Consequently, the courts can directly apply the Constitution only if the Constitutional Court has found the unconstitutionality of a legislative solution and authorized, by that decision, the direct application of some constitutional provisions in the absence of a legal regulation of the legal situation created by the decision of the unconstitutionality exception admission.

The Court has further held that, in Romania, the constitutional control is carried out by the Constitutional Court, the only constitutional jurisdiction authority [Article 1 para. (2) of the Law no. 47/1992], thus the Constitutional Court has ruled that, according to the Fundamental Law, the only authority empowered to exercise the control of laws and ordinances constitutionality is the constitutional court. Therefore, neither the High Court of Cassation and Justice nor the courts or other public authorities of the State have the power to control the constitutionality of laws or ordinances, whether or not they are in force [Decision no. 838 of May 27, 2009, published in the Official Journal of Romania, Part I, no. 461 of July 3, 2009]. Under Article 142 para. (1) of the Constitution, the Constitutional Court is the guarantor of the supremacy of the Fundamental Law and, according to Article 1 para. (2) of the Law no. 47/1992, it is the only authority of constitutional jurisdiction in Romania. In other words, in accordance with the constitutional and legal provisions into force, only the Constitutional Court is entitled to control the Government's simple or urgent ordinances, no other public authority having material competence in this area [Decision no. 68 of February 27, 2017, published in the Official Journal of Romania, Part I, no. 181 of March 14, 2016, paragraph 79]. According to the provisions of Article 146 letter d) of the Constitution, corroborated with those of Law no. 47/1992 on the organization and operation of the Constitutional Court, it is the only competent authority in the matter of constitutionality control, excluding any sharing in this respect with the courts of common law (Decision no. 766 of June 15, 2011, published in the Official Journal of Romania, Part I, no. 549 of August 3, 2011]. The Court has also found that a dimension of the Romanian state is constitutional justice, carried out by the Constitutional Court, a political-judicial public authority that is outside the sphere of legislative, executive or judicial power, its role being to ensure the supremacy of the Constitution as Fundamental Law of the rule of law [Decision no. 727 of July 9, 2012, published in the Official Journal of Romania, Part I, no. 477 of July 12, 2012]. 
Giving a decision-making role to the courts in carrying out the constitutional control implies, on the one hand, the interpretation of the constitutional notions and concepts, the determination of the sphere and limits of the fundamental rights and freedoms, or the explanation of the organization and functioning in the framework of the constitutional law relations of the state authorities and, on the other hand, the creation of a hybrid model of constitutionality control unprecedented in other states of the world. Thus, the competence of the Constitutional Court, which would remain in the sphere of the norms' constitutional contentious, would be undermined, and the courts would take over the competence to concretely apply in the concerned cases the provisions of the Constitution, the final act of the judgement - the judicial decision thus becoming the subject of the constitutionality control of the common law judge.

It should be noted that, based on the exception of unconstitutionality, the a quo judge is only allowed to express his opinion on the merits of the exception, as an aid given to the constitutional court, but, instead, his competence to make that assessment convertible itself in a condition of admissibility of the exception is denied. The reason why the legislator did not set such a condition of admissibility is precisely the fact that the a quo court would carry out a constitutional control, the results of which would depend on the notification of the Constitutional Court.

However, this view of the exercise of constitutionality control is undermined by the legal provisions under consideration, which recognize the decision-making power of the courts both with regard to the establishment of the meaning of the constitutional norm and with regard to the in concreto examination of the constitutionality of the deduced document.

Having clarified the issue of the competent authority to exercise the constitutional control, the Court held that, now, the provisions of Article 146 letter a), first sentence, and letters d) and b), c) and para. (1) of the Constitution, corroborated with Article 27 para. (I) of the Law no. 47/1992 expressly regulates the constitutionality control, on the one hand, of the normative acts of primary regulation and, on the other hand, the international treaties, the regulations and the parliamentary decisions. Thus, the constitutional control of court judgments, by unconstitutionality complaint, it is not yet normed. The Court therefore notes that the exercise of a constitutional control over the judgment decisions implies a check of their compliance with the Constitution, this control can only be made by the Constitutional Court and not by the courts, and the decision of the constitutional court thus pronounced may constitute a reason for review of the court decision cancelled on grounds of unconstitutionality.

But it is not possible to carry out a constitutional control of the court's decision by the competent court to hear a revision petition because it would end up with the defeat of the unlimited jurisdiction of the Constitutional Court over the constitutionality control. Otherwise, the Constitution would become subject to more or less heterogeneous interpretations at the level of all existing courts in Romania. It is also 


\section{Unconstitutional legislative solutions enshrined by the Civil Procedure Code}

obvious that, under these coordinates, the extraordinary appeal to the review is not the appropriate legal means for the constitutional control of judgment decisions.

Consequently, the Court found violation of the constitutional provisions of Article 142 para. (I), according to which the Constitutional Court is the guarantor of the supremacy of the Constitution, as well as of Article 124 para. (1) and Article 126 para. (1) according to which justice is made in the name of the law by the High Court of Cassation and Justice and by the other courts provided by law.

For the same reasons, the Court, based on the Article 18 para. (1) of the Law no. 47/1992, is going to extend its constitutionality control over Article II point (1) of the Law with reference to Article 509 (I) point 14 of the Civil Procedure Code, because the assessment of the judgment compliance with the decisions of the Constitutional Court is also an aspect of constitutional control on the unconstitutionality complaint. Therefore, this legal text also infringes Article 124 (I), Article 126 (1) and Article 142 (1) of the Constitution. In fact, assessing the compliance of a legislative solution with the Constitutional Court's decisions is, also, an aspect of constitutional control through Article 147 (4) of the Constitution regarding the observance of the generally binding effects of the decisions of the Constitutional Court [see Decision no. 581 of July 20, 2016, published in the Official Journal of Romania, Part I, no. 737 of September 22, 2016, paragraph 49 et seq., or Decision no. 681 of November 23, 2016, published in the Official Gazette of Romania, Part I, no. 1000 of December 13, 2016, paragraph 21 et seq.). Furthermore, the Constitutional Court is competent to decide on the unconstitutionality situation created by non-observance of the considerations of an unconstitutionality finding decision [Decision no. 463 of September 17, 2014, published in the Official Journal of Romania, Part I, no. 704 of September 25, 2014, paragraph 37].

The Court also found that the legislator started from a correct premise in terms of Article I para. (5) of the Constitution, referring to the observance of the Constitution by all the public authorities, including the courts through the pronounced judgments, but it has regulated a defective legal mechanism both with regard to the competent authority to make the constitutional control and with regard to the procedural manner in which it is carried out.

Considering Article 18 para. (1) of the Law no. 47/1992, the Court extended the constitutionality control to Article II para. (1) of the Law with reference to Article 509 para. (1) point 15 of the Civil Procedure Code in relation to Article 1 para. (5) of the Constitution in its component concerning the quality of the law. In this regard, the Court finds that this legal text establishes as review reason the delivery of some sanctions on the basis of some legal provisions which were not in force at the time when the legal report brought before aroused. However, in civil procedural matters, the sanctions are defined, in the doctrine, as coercive measures designed to ensure compliance with the legal norms prescribing the forms and conditions under which judicial activity in civil matters must be developed. They have a dual function: to prevent participants in the civil process to observe procedural discipline and to sanction the ones who violate it.

CONSTITUTIONAL NEWS 
These may be nullity, preclusion, extinction, suspension of the case, court fines, limitation of the right to ask forced execution, damages for the injured party or in civil matters nullity, reduction, unenforceability, extinctive prescription, acquisitive prescription etc. The legally criticized text, as it is drafted, referring to the date when the legal report brought before aroused, seems to refer to civil sanctions. Considering the importance of the revision - an extraordinary way of attack that can annihilate the authority of res judicata of the court decision - it is compulsory for the legislator, by Article 1 para. (3) and (5) of the Constitution, to indicate expressly and unequivocally these cases, without appealing to classifications not explicitly supported by the normative text of the Civil Procedure Code or the Civil Code, because, in the end, the civil sanction or the civil procedure is concept notion, including specific notions. Moreover, in principle, the review motives refer to unknown matters at the time of the trial; legality aspects pleaded concerning the judgment being censured by way of appeal [see the repeal reason foreseen in Article 488 para. (I) point 8 of the Civil Procedure Code - "when the judgment was given with the wrongful violation or application of the substantive law norms"]. Hence, from this point of view, such a legislative orientation appears to be questionable, making confusion between the reasons which intrinsically can be the object of the review, respectively of the appeal.

Consequently, the Court held that Article II para. (1) of the Law with reference to Article 509 para. (1) point 15 of the Civil Procedure Code infringes the constitutional provisions of Article 1 (3) on the rule of law and paragraph (5) on the quality of laws.

Considering Article 18 para. (I) of the Law no. 47/1992, the Court has extended its constitutionality control to Article II points 2 and 3 of the Law, as these legal texts establish, on the one hand, the typology of the judgments which can be reviewed in the application of the newly-regulated review motives and, on the other hand, their exercising terms. The Court has held, mutatis mutandis, the violation, by these texts, of the constitutional provisions infringed by the law texts regulating the new revision motives, namely Article 1 para. (3) and (5), Article 124 para. (I), Article 126 para. (I), Article 142 para. (I), Article 147 para. (4) of the Constitution.

For the given reasons, the Court admitted the formulated objection of unconstitutionality and notes that the provisions of Articles II and III of the Law approving the Government Emergency Ordinance no. 95/2016 for the extension of some deadlines and for the establishment of the necessary measures for some provisions preparing for implementation of the Law no. 134/2010 on the Civil Procedure Code are unconstitutional.

Decision no. 377 of May 31, 2017 regarding the objection of unconstitutionality of the provisions of the Law on the approval of the Government Emergency Ordinance no. 95/2016 for the extension of certain terms, as well as for the establishment of some measures necessary for the preparation of the implementation of some provisions of Law no. 134/2010 on the Civil Procedure Code, published in the Official Journal no. 586 of July 21, 2017 
Unconstitutional legislative solutions enshrined by the Civil Procedure Code

Setting in the court of appeal competence to solve the transfer request

based on legitimate suspicion is constitutional insofar as the reason for

legitimate suspicion does not relate to a the quality of judge at the court

of appeal of one of the parties, namely whether the reason for legitimate

suspicion is not related to the quality of being part of the appeal court

within the jurisdiction of which the court in charge of hearing the case

develops its activity

The texts criticised in the Civil Procedure Code have the following content:

- Article 142 para. (I) first sentence: "The request for transfer based on legitimate suspicion is within the competence of the appeal court if the court from which the transfer is requested is a court or a tribunal within its jurisdiction. If the transfer is requested from the appeal court, the resolution competence belongs of the High Court of Cassation and Justice. The transfer request shall be submitted to the competent court to solve it, who shall immediately notify the court from which the transfer was requested regarding the request for transfer".

- Article 145 para. (I) first sentence: "If the transfer request is admitted, the court of appeal sends the trial to be judged by another court of the same level in its constituency. The High Court of Cassation and Justice will transfer the judgement of the case to one of the courts of the same level in the jurisdiction of any of the appeal courts adjoining with the court of appeal in whose jurisdiction is the court from which the transfer is requested".

The Court noted, with reference to the precedent given by Decision no. 558 of October 16, 2014, published in the Official Journal of Romania, Part I, no. 897 of December 10, 2014, that the transfer is one of the procedural means that contributes to ensuring the effective character of the judges' impartiality, institutional guarantee of the right to a fair trial. As regards the court having competence to resolve the transfer request, the Court held that it was the High Court of Cassation and Justice in the previous civil procedural regulation. Currently, the Supreme Court has the power to resolve only transfer requests based on public security grounds, as well as those referring to the transfer of cases from the courts of appeal. In the current civil procedural law, the competent court to settle the transfer request based on legitimate suspicion is the appeal court in whose jurisdiction is the court from which the transfer of the trial is requested, a court of appeal which, according to Article 145 of the Civil Procedure Code, in case of admission of the transfer request, will send the trial to be judged by another court of the same level in its constituency. Suspicion is considered legitimate in cases where there is doubt about the impartiality of judges due to the circumstances of the trial, the quality of the parties or of local conflictual relations [Article 140 para. (2) of the Civil Procedure Code]. 
Also, reiterating its jurisprudence and that of the European Court of Human Rights, the Court has pointed out that the impartiality of the magistrate, as a guarantee of the right to a fair trial, must be appreciated in a double sense: subjective and objective. The subjective approach tends to determine the personal conviction of a judge in a particular cause, which signifies the so-called subjective impartiality, which is presumed up the contrary. The objective approach aims to determine whether it has provided sufficient guarantees to exclude any legitimate doubt about it, which means so-called objective impartiality. The objective appreciation of impartiality consists in analysing whether, independently of the judge's personal conduct, certain circumstances that can be verified give rise to suspicions concerning a possible lack of impartiality. The Court therefore held that the objective impartiality of the judge is criticised in that cause, given by the quality of the judge applicant at the appeal court, hence a possible court of judicial control.

The Court has also held that the criticized legal rules do not meet the purpose for which they were provided, respectively they can't remove the doubts concerning the partiality of the court. The Court also emphasized that, in the assessment of the objective impartiality, the appearances have a special role, because in a democratic society the courts must inspire full confidence to the litigants.

The Court concluded that the provisions of Article 142 para. (1) first sentence and Article 145 para. (1) first sentence of the of Civil Procedure Code appear as being unconstitutional, violating the principle of justice impartiality contained in Article 124 para. (2) and, implicitly, the right to a fair trial provided by Article 21 para. (3) of the Constitution, in so far as the reason for legitimate suspicion relates to the quality of the judge at the appeal court in whose jurisdiction is the court which will judge the cause. Consequently, in view of the above, the competence to resolve such transfer requests cannot be relied upon by the Appeal Court. That is why, in the given situation, the transfer is to be made from the court of appeal area, a concept with the same purpose and legal significance as the "from the appeal court", thus being applicable, mutatis mutandis, in this hypothesis, the second theses of the Article 142 para. (I) of the Civil Procedure Code.

The Constitutional Court also held that, according to Article 147 para. (1) of the Constitution, it is in the task of the legislator to reconfigure the rules of competence concerning the transfer, under the conditions of the Article 122 of the of Civil Procedure Code, in compliance with the observance of the decision mentioned before, and to create a mechanism capable of overcoming the deficiencies concerning the application of the Article 142 para. (1) first sentence and the Article 145 para. (1) first sentence of the Civil Procedure Code, possibly by adapting, for example, Article 127 of the Civil Procedure Code.

Similarly, when the legitimate suspicion is based on the quality of the parties, that is, on the quality of the Appeal Court as correspondent party in the dispute, there are objective elements that lead rightly to doubts about the impartiality of the court. The 
Unconstitutional legislative solutions enshrined by the Civil Procedure Code

transfer to another court in the jurisdiction of the same court of appeal is not, in all cases, sufficient to remove the reasons of legitimate suspicion which were at the base of the transfer measure, meaning that they will exist at any court in the jurisdiction of the same appeal court.

Decision no. 169 of March 24, 2016 on the unconstitutionality exception of the Article 142 para. (1) first sentence and Article 145 para. (1) first sentence provisions from the Civil Procedure Code, published in the Official Journal no. 353 of May 9, 2016

See, mutatis mutandis, Decision no. 558 of October 16, 2014, published in the Official Journal of Romania, Part I, no. 897 of December 10, 2014

3. It is unconstitutional the condition of evocating the merits as a condition

for the admissibility of the final judgments review request based on judgments delivered by the European Court of Human Rights by which have been found violations of fundamental rights or freedoms or based on the violations of European Union law, as it is interpreted

by the Court of Justice of the European Union as well as a condition for the admissibility of the judgments review based on a provision concerning which the objection of unconstitutionality was raised and, once the judgment has become final, the Constitutional Court ruled on the exception invoked in that case, declaring unconstitutional the provision that was the subject of that exception

The object of the unconstitutionality exception is the provisions of Article 509 para. (1) point 1 and 2 of the Civil Procedure Code, according to which: "(1) Revision of a judgement ruled on the substance or which evoke the merits may be required if: [...] 11. after the judgment has become final, the Constitutional Court has ruled on the exception raised in that case, declaring the provision which was the subject of that exception unconstitutional. (2) For the revision reasons provided in paragraph (I), point 3 , but only in the case of the judge, point 4, points 7-10 shall be subject to review also the decisions which don't evoke the merits".

The Court held that, in the present case, the authors of the unconstitutionality exception criticize the provisions of the Article 509 para. (I) points 1 and 2 of the Civil Procedure Code in terms of the condition that as a judgment to be reviewed it must be ruled on the substance or it should evoke the merits. They point out that in the case of final court decisions by which, without evocating the merits, the action was dismissed and the Constitutional Court found that the legal provision regarding the term of 
exercising the action is unconstitutional, that decision cannot be the subject of a revising demand under Article 509 para. (I) point 11 from the Civil Procedure Code.

The Court has also analysed the condition of evocating the merits as an admissibility condition of the revision request of the final judgments based on the judgments delivered by the European Court of Human Rights by which were found violations of fundamental rights or freedoms or based on the violations of the EU law, as interpreted by the European Court of Justice. Thus, the Court held that the requirement to evoke the merits in such situations is contrary to the Fundamental Law and found, by Decision no. 233 of February 15, 2011, published in the Official Journal of Romania, Part I, no. 340 of May 17, 2011, that the provisions of the Article 322 point 9 of the Civil Procedure Code from 1865 are unconstitutional insofar as they do not allow the review of a court decision by which, without evocating the merits, have been violated fundamental rights and freedoms, violations found by the European Court of Human Rights. By Decision no. 1.039 of December 5, 2012, published in the Official Journal of Romania, Part I, no. 61 of January 29, 2013, the Court found that the provisions of the Article 21 para. (2) first sentence of the Administrative Contentious Law no. 554/2004, published in the Official Journal of Romania, Part I, no. 1.154 of December 7, 2004, are unconstitutional insofar as they are interpreted that they can't be subject to final and irrevocable judgments revisions of the appeal courts, by violation of the priority principle of the European Union law, when they do not evoke the merits of the case.

The provisions of Article 509 para. (I) of the Civil Procedure Code are procedure rules and, in accordance with the provisions of Article 126 para. (2) and Article 129 of the Constitution, the trial procedure and the enforcement of the requests for appeals against court decisions are set only by law. From these constitutional norms it turns out that the legislator has the freedom to determine the conditions in which the interested parties and the Public Ministry can exercise requests for appeals, in compliance with the norms and principles enshrined in the Fundamental Law.

The review, being an extraordinary remedy promoted to correct the errors as to the facts, aims at restoring the truth in question, which is fully in line with the provisions of the Article 124 of the Constitution on the justice enforcement (see, to that effect, Decision no. 3 of January 18, 2011, published in the Official Journal of Romania, Part I, no. 192 of March 21, 2011, or Decision no. 76 of February 12, 2013, published in the Official Journal of Romania, Part I, no. 209 of April 12, 2013).

The provisions of Article 509 para. (I) point 11 of the Civil Procedure Code give legal effect to the decisions of the Constitutional Court which establish the unconstitutionality of laws or ordinances or provisions thereon, namely the right of the persons foreseen by the law to exercise the extraordinary request for appeal of the review against the final judgment by which was solved the case in which the exception was invoked (see, in this respect, Decision no. 1.106 of September 22, 2010, published in the Official Journal of Romania, Part I, no. 672 of October 4, 2010). This review motive applies only to judgments which concern the substance, since the provisions of 


\section{Unconstitutional legislative solutions enshrined by the Civil Procedure Code}

Article 509 para. (2) of the Civil Procedure Code do not list it among the reasons which may be invoked for the review of judgments which do not evoke the merits.

However, irrespective of the law-maker's option to regulate an appeal seeking to reform a court decision, the essential objective of such a procedural way is to deliver a legal and duly justified judgment which reflects the truth by returning to the estate of legality in conformity with the Fundamental Law. A judgment which is not given on the substance or which does not evoke the merits, although definitive, cannot be considered legal as long as it is based on a legal provision contrary to the Constitution. By excluding from the possibility of a review based on the unconstitutionality finding of a legal provision by the Constitutional Court following the resolution of the unconstitutionality exception, having as subject that provision, invoked in the case, of the final decisions, but which do not concern the substance, it is reached the situation in which the litigants cannot benefit of an effective instrument to protect his constitutional rights. Noticing this aspect, the Court has repeatedly decided in the recitals of its decisions - both compulsory (see, to that effect, paragraph 23 of this decision) - that the review based on the provisions of Article 322 of the Civil Procedure Code from 1865 or Article 509 of the Civil Procedure Code may be exercised by the person to whom the exception was granted and by the person to whom the exception was dismissed as inadmissible without distinction that the judgement whose revision is required concerns or not the substance. By the very Decision no. 616 of November 4, 2014, according to which the authors of the unconstitutionality exception request the revision of the decision pronounced without evocating the merits, the Court held in paragraph 16 that the previous admission of the unconstitutionality exception decision, namely Decision no. 269 of May 7, 2014 may be the basis of a review request under Article 322 point 10 of the Civil Procedure Code from 1865 or Article 509 para. (I) point 11 of the Civil Procedure Code, as appropriate, according to the applicable civil procedural law.

In the judicial process, the exception of unconstitutionality is one of the procedural exceptions intended to prevent a judgment which could be based on an unconstitutional legal provision. Finding the unconstitutionality of a legal text following the invoking of an unconstitutionality exception must be useful to it's authors and cannot be merely an abstract law instrument as it would lose its concrete character (see, to that effect, Decision no. 766 of June 5, 2011, or Decision no. 338 of September 24, 2013, published in the Official journal of Romania, Part I, no. 699 of November 14, 2013). The unconstitutionality of a legal provision does not have only a preventive function, but also a remedy one, since it primarily concerns the concrete situation of the citizen who has suffered prejudice of his rights by the criticized norm.

By dismissing as inadmissible a revision request based on the provisions of point 11, para. (I) of the Article 509 from the Civil Procedure Code, because the judgment whose revision is requested does not engage the substance, the control of constitutionality itself it is ineffective, since the parties are unable to benefit from the effects of the Court's decision, thus of the constitutionality control they have triggered,

CONSTITUTIONAL NEWS 
which is a genuine sanction applicable to them. Thus, the binding decisions of the Constitutional Court would not have any legal effects, and the constitutional court's role would be denied. In addition, it amounts to an unjustified limitation on an appeal.

Romania is a state based on the rule of law, according to Article 1 para. (5) of the Constitution, "compliance with the Constitution, its supremacy and laws is mandatory". According to Article 142 para. (1) of the Constitution, the Constitutional Court is the "guarantor of the Constitution supremacy" and its decisions are "generally binding and have power only for the future", according to Article 147 para. (4) of the Fundamental Law. On these constitutional provisions is based the compulsoriness of erga omnes expression, of the interpretation and the solution pronounced by the Constitutional Litigation Court, which implies the constitutional obligation of all authorities to apply the Court's decisions precisely to the concrete situations in which have an incidence the norms declared unconstitutional.

The decision to declare unconstitutionality must be useful to those entitled, even if in the case in which was invoked the unconstitutionality exception of that provision was delivered a final judgement by which it did not get into the investigation of the substance. In such a case, the regulation of the condition of evocating the merits as a condition for the admissibility of the revision request of that judgment violates Article 147 para. (4) of the Constitution, the free access of the citizens to justice, guaranteed by Article 21 of the Fundamental Law, equal rights and the principle of the Constitution supremacy and the legality principle.

The Court upheld the unconstitutionality exception and found that the phrase "rulled on the substance or which evoke the merits" from Article 509 para. (I) of the Civil Procedure Code is unconstitutional with reference to the revision reason foreseen at point 11 of their content.

Decision no. 866 of December 10, 2015 on the exception of the unconstitutionality of the provisions of the Article 509 para. (1) point 11 and para. (2) of the Civil Procedure Code, published in the Official Journal no. 69 of February 1, 2016

See, mutatis mutandis, Decision no. 233 of February 15, 2011 on the unconstitutionality exception of the provisions of the Article 322 point 9 of the Civil Procedure Code, published in the Official Journal no. 340 of May 17, 2011

\section{It is unconstitutional to include, in the admissibility of the appeal in} principle stage, the decision to dismiss the appeal as manifestly unfounded

The object of the unconstitutionality exception is represented by the provisions of Article 493 para. (5)-(7) of the Civil Procedure Code, according to which: "(5) If the formation unanimously agrees that the appeal does not meet the formal requirements, that the grounds for the cassation claimed and their development do not fall within the scope of the Article 488, or that the appeal is manifestly unfounded, annuls or, as the 
case may be, dismisses the appeal by a reasoned decision, pronounced, without the parties being summoned, who is not subject to any appeal. The decision shall be communicated to the parties. (6) If the report considers that the appeal is admissible and all members agree, and the legal issue to be appealed is not controversial or is subject to constant case law of the High Court of Cassation and Justice, the formation may decide upon the substance of the appeal, without notice of the parties, by a final decision, which shall be communicated to the parties. For the resolution of the appeal the court will take into account the points of view of the parties formulated according to paragraph (4). (7) If the appeal cannot be resolved in accordance with paragraphs (5) or (6), the formation will pronounce, without noticing the parties, a termination of the admission in principle of the appeal and will fix the time of the judgement on the substance of the appeal, by noticing the parties".

The Court held that the dismissal of the appeal on the ground that it was manifestly unfounded supposes the examination on the substance of the appeal, involving the examination of certain aspects which aim at the merits of the request which is the subject of the appeal; either, the procedure for examining the admissibility of the appeal must be limited to purely formal matters. By the decision given in this case, without the parties being summoned and without the possibility of appealing against it, the Court considers that the parties cannot achieve their rights to defence and to contradictory debates, thus violating the right to a fair trial. Thus, the case-law of the Constitutional Court is placed on the coordinates of a process governed by the principles of adversarial, procedure orality and transparency of the judicial process, thereby ensuring the citizen's confidence in the way in which it is achieved (see, to that effect, ad similis, in civil procedural matters the Decision no. 194 of April 27, 2004, published in the Official Journal of Romania, Part I, no. 523 of June 10, 2004, or Decision no. 757 of November 5, 2015, published in the Official Journal of Romania, Part I, no. 20 of January 12, 2016, and in the criminal procedure law the Decision no. 599 of October 21, 2014, published in the Official Journal of Romania, Part I, no. 886 of December 5, 2014, or the Decision no. 630 of October 8, 2015, published in the Official Journal of Romania, Part I, no. 878 of November 24, 2015). Therefore, justice must not be hidden, secret, on the contrary, it must ensure the effective participation of the parties in order to fully perform the judicial process. The legislator must, of course, establish in a restrictive way the reasons under which the act of justice would be carried out without the participation of the parties, but when are being discussed substantive matters of the cause, it has no constitutional right to regulate a procedure which does not imply the possibility, for the parties, to present their views, submissions or requests. Only in this way can be assured for the parties the accessibility of the judicial proceedings.

The "manifestly unfounded" nature of the appeal does not entitle the legislature to place an issue concerning the substance of the appeal at an earlier procedural stage in which the substance of the case are not dealt with or settled. The inclusion of the decision to reject the appeal as manifestly unfounded at the admissibility of the appeal

CONSTITUTIONAL NEWS 
in principle stage circumvent the purpose and the reason of this step (in this respect is, mutatis mutandis, also the Decision no. 591 of October 1, 2015, published in the Official Journal of Romania, Part I, no. 861 of November 19, 2015).

For these reasons, the Court held that the phrase "or that the appeal is manifestly unfounded" in Article 493 para. (5) of the Civil Procedure Code is unconstitutional because the dismissal of the appeal on the ground that it is manifestly unfounded compels the High Court of Cassation and Justice to examine the substance of the case, and this may only take place at the stage when the appeal is judged on the substance, which is made in accordance with Article 493 para. (6) or Article 494 of the Civil Procedure Code, where the case is sent in view to judge the appeal on the substance. Under these circumstances, the examination of the substance of the appeal will be done in compliance with all procedural guarantees specific to the free access to justice, the right to a fair trial and the rights to defence, including the parties' summons and the prosecutor's participation when appropriate.

Decision no. 839 of December 8, 2015 on the unconstitutionality exception of the provisions of Article 493 para. (5)-(7) of the Civil Procedure Code, published in the Official Journal no. 69 of February 1, 2016

5. The mandatory legal representation of natural and legal persons, by lawyer, in filing the second appeal is unconstitutional. The mandatory representation and assistance by legal adviser or lawyer to file a second appeal is equivalent to an admissibility criterion regarding the lodging of a means of appeal

The Court comprised that in relation to the legal framework of the institution responsible for the conventional representation of the parties during Court proceedings, the Civil Procedure Code provides, as standard rule for Article 13 - The rights of defense -, comprised in Chapter II - Basic principles of the lawsuit - regarding preliminary ruling Scope of the Civil Procedure Code and the fundamental principles of the lawsuit -, the mandatory conventional representation for a second appeal, of both natural persons, by legal adviser or lawyer. In Section 4 - Representation of Parties in Court Proceedings - in Chapter II - Parts - of Title II - Participants in a party's lawsuit - of the first Book General provisions -, the Civil Procedure Code divides the forms of representation into legal, conventional or judicial and in what concerns conventional representation, the Code specifically sets rules for natural persons and legal persons. Thus, Article $83-$ Conventional representation of natural persons -, para. (3), refers only to the mandatory conventional representation of natural persons by lawyer, during the second appeal stage. The similar text applicable to legal persons is constituted by the provisions of 


\section{Unconstitutional legislative solutions enshrined by the Civil Procedure Code}

Article 84 para. (2), of the Code, article under the legal name of Conventional Representation of Legal Persons. Article 486 para. (3) of the Civil Procedure Code regulates the second appeal nullity in case of non-fulfilment of the claims arising from the obligation to formulate and support the second appeal, for natural persons, and by legal adviser or lawyer, for legal entities.

By Decision no. 462 of September 17, 2014, published in the Official Journal of Romania, Part I, no. 775 of October 24, 2014, the Court admitted the unconstitutionality exception and ascertained the provisions of the Civil Procedure Code under Article 13 para. (2) second sentence, Article 83 para. (3), and in Article 486 para. (3) with reference to the statements resulting from the obligation to state and support the claim for a second appeal by a lawyer as unconstitutional, being contrary to Article 21 and Article 24 of the Fundamental Law. In this respect, the Court comprised, in essence, that access to justice is not an absolute right and it may be hindered by certain formal and substantive conditions imposed by the legislator, by referring to the provisions of Article 21 of the Constitution. These conditionings cannot be accepted if they affect the very essence of the fundamental right. Consequently, limitations to the fundamental right are admissible only provided they target a legitimate purpose while there is certain proportionality between the means used by the legislator and the aim pursued by him/her (25). By imposing the incumbency of a lawyer to represent and assist the parties, as criterion for the admissibility of lodging a means to appeal, the legislator has set a limit to the free access to justice, aspect which constitutes a real intervention of the state in the process of configuring and structuring of this right fundamental. Furthermore, the Court has also ascertained that in essence, such interference on the part of the State is allowed precisely due to the nature of the right stipulated under Article 21 of the Constitution, which inherently implies a state regulation (28). Since the lodging of a means of appeal is but a facet of free access to justice and being the case of an intervention on the part of the state, the Constitutional Court analysed, in the light of a proportionality test developed in accordance with and under its case- law, whether the limits imposed by the intervention of the legislator this right - that is, the regulation of the incumbency of representation and assistance by a lawyer in the trial stage of the second appeal, respectively - represent a reasonable limitation that is not disproportionate in regard to the pursued objective and that does not turn the right into an insubstantial one. Subsequent to the proportionality test, the Court concluded that the measure of representation and assistance by a lawyer in the trial stage of the second appeal is not proportionate to the purpose pursued by the legislator, the public advantage being insignificant in relation to the degree of impairment of individual's fundamental rights and freedoms, those established under Articles 21 and 24 of the Constitution (50), respectively. The Court also considered legal criticized provisions as having also redounded on the rights to defense, from the respondent's perspective as consequence of appellant's exercising of rights of free access to justice, but the legal

CONSTITUTIONAL NEWS 
criticized provisions infringe Article 24 of the Constitution, guarantee of the right to a fair trial and from appellant's point of view too, as this constitutional provision does not only concern defense during proceedings before the lower court but also the right of defense by lodging means of appeal against factual or legal findings or solutions adopted by a court and which are found to be wrong by one or another of the parties taking part in the proceedings, in the instance the interested party is prevented from lodging exercising his/her means of appeal, not being able to capitalize and defend his/her rights before the court of appeal (51). In conclusion, the Court considered the obligation of representation and assistance by a lawyer in the lodging of the second appeal as equivalent, in the first place, to a transformation of the content of this fundamental right into a criterion of admissibility of lodging a means of appeal and, on the other hand, to a conversion of this right into an obligation affecting the essence of the rights of defense as stipulated in the Constitution. However, the legislator cannot assign various attributes, practically contrary to its character of granting the right to a fair trial (52) as stipulated in the Constitution. The criticized legislative solution creates the premises for the transformation of the free access to justice and of the right to defense into insubstantial rights that which is not likely to lead to the continuous, natural consolidation of the state founded on the rule of law, which attracts its unconstitutionality (54).

In this case, the Court ascertained that legal provisions of the Civil Procedure Code are criticized in terms of violation of Article 21 concerning free access to justice and Article 24 concerning the right of defense stipulated in the Constitution, whit regards to legal persons.

The Court noticed statutory entities as well as any other legally founded organizations (institutions) to be legal persons. Legal entities are whether governed by public or by private law. Legal entities governed by private law may freely constitute one of the law provided forms while legal persons governed by public law are established by law or, by way of exception, by acts originating with the central or local public administration authorities or by other law stipulated means (Article 188 et seq. of the Civil Code). In what concerns the legal persons, the provisions of Article 209 of the Civil Code stipulate that the abovementioned persons exercise their rights and fulfil their duties through their management bodies, beginning with the date of incorporation. A legal person's managing bodies may be natural as well as legal individuals, who by law, articles of incorporation or statute are designated to act in relationships with third parties, individually or collectively, in the name and on behalf of the legal person (see also Decision no. 633 of November 11, 2014, published in the Official Journal of Romania, Part I, no. 16 of January 9, 2015, para. 20). According to Article 21 para. (1)-(3) of the Local Government Authorities Law no. 215/2001, republished in the Official Journal of Romania, Part I, no. 123 of February 20, 2007, with its subsequent modifications and completions, the administrative and territorial divisions are legal entities governed by public law with full legal capacity and own 


\section{Unconstitutional legislative solutions enshrined by the Civil Procedure Code}

patrimony. In the court of law, the administrative and territorial divisions are represented, as the case may be, by the mayor or by the president of the county council. In order to defend the interests of the administrative and territorial divisions, the mayor, the president of the county council, respectively, is summoned before the Court as legal representative, not on his/her own behalf. However, in the case of legal representation too, assistance and representation by lawyer or legal adviser are mandatory in the second appeal, in the case of legal persons. Hence, according to Article 80 para. (5) of the Civil Procedure Code, "When the right of representation originates with the legislation or court order, the lawyer's assistance is not compulsory. Provisions of Article 83 para. (3) and Article 84 para. (2) are applicable".

In what concerns the applicability of legal persons' fundamental rights and freedoms, the Court noticed that although Article 21 regarding free access to justice is contained in Chapter I - Common Provisions - and Article 24 of the fundamental law on the right to defense is contained in Chapter II - Fundamental rights and freedoms - in Title II - Fundamental rights, freedoms and duties stipulated in the Constitution -, it is obvious that granting free access to justice and the right to defense must be awarded to legal persons also, not only to natural persons. In this respect, concerning the application of legal persons' fundamental rights and freedoms, the Court considered, in its case-law, that they also apply to legal persons insofar as the citizens exercise a constitutional right through them (see to that effect Decision no. 35 of April 2, 1996, published in the Official Journal of Romania, Part I, no. 75 of April 11, 1996). In order to complete its case-law regarding this issue, the Court considers, by way of example, that by several decisions (Decision no. 40 of January 29, 2004, published in the Official Journal of Romania, Part I, no. 229 of March 16, 2004, Decision no. 1.360 of October 27, 2009, published in the Official Journal of Romania, Part I, no. 874 of December 15, 2000, Decision no. 5 of February 4, 1999, published in the Official Journal of Romania, Part I, no. 95 of March 5, 1999, or Decision no. 498 of May 10, 2012, published in the Official Journal of Romania, Part I, no. 428 of June 28, 2012) it has stated that requirements of certain fundamental rights or freedoms, such as free access to justice, individual freedom, right to private property or economic freedom also apply to legal persons. Consequently, the requirements and guarantees resulting from the fundamental rights and freedoms regulated by the Constitution also apply to legal persons, to the extent that their regulatory content is compatible with the nature, specificity and particularities characterizing the relevant legal person's legal framework.

Based on this premise, the need to acknowledge the guarantees regarding the entitlement to legal persons' fair trial, and applying the mutatis mutandis reasoning, as comprised in the Decision no. 462 of September 17, 2014, regarding the incumbent representation of natural persons for a second appeal by a lawyer, the Court found the obligation to be represented and assisted by a legal adviser or lawyer in a second appeal as equivalent to the criterion of admissibility to lodge a means of appeal; on the other hand, the right to benefit from a conventional representative is transformed into an 
obligation in the case of a second appeal. Regarding the legal persons (whether governed by public or private law), the criticized law restricts free access to justice as well as the rights to defense, which requires the review, by means of proportionality test, of the limits imposed by legislator' intervention - the regulation of the obligation to represent and assist legal persons by a legal adviser or lawyer in the proceedings of a second appeal, respectively - whether they represent a reasonable limitation that is not disproportionate to the pursued objective and does not transform the right into an insubstantial one. In conclusion, the provisions of the criticized law contravene Article 21 with regard to free access to justice and Article 24 concerning the rights to defense, because the measure having determined the limitation of the right to free access to justice (namely the institution of the incumbent conventional representation in the second appeal) is excessive towards the pursued legitimate aim, leading to the impossibility to initiate a second appeal as stipulated by law. The European Court of Human Rights which, in interpreting Article $6 \S 1$ of the Convention, by Decision of July 10, 2001 in the Tricard v. France case, decreed the regulations regarding the necessary formalities to declare a means of appeal as aiming to ensure the proper administration of justice and observance of the principle of legal certainty. However, the relevant rules should not prevent the individual from using an available means of appeal (paragraph 29).

The Court admitted the unconstitutionality exception and ascertained the provisions of Article 13 para. (2) second thesis, of Article 84 para. (2), as well as of Article 486 para. (3) of the Civil Procedure Code, with reference to the claims arising from the obligation of legal persons to formulate and support the request for a second appeal by lawyer or legal advisor, as unconstitutional.

Decision no. 485 of June 23, 2015 on the exception of the unconstitutionality of the provisions of Article 13 para. (2), second thesis, Article 84 para. (2) and Article 486 para. (3) of the Civil Procedure Code, published in the Official Journal no. 539 of July 20, 2015

See, mutatis mutandis, Decision no. 462 of September 17, 2014, published in the Official Journal of Romania, Part I, no. 775 of October 24, 2014

\section{The lack of precisely determining the competent enforcing authority is unconstitutional}

The object of the unconstitutionality exception is represented by the provisions of Article 650 para. (1) of the Civil Procedure Code, according to which: "The enforcing court is the district court in the jurisdiction of which the office of the bailiff carrying out the enforcement procedure is located, except where the law stipulates it otherwise". 
Considering the constitutional provisions of Article 124 para. (2), according to which "Justice is but one, impartial and equal for all", the Court considered the act of justice, for the purposes of Article 124 of the Constitution, as the exclusive attribute of the district courts, while the criticized legal provisions refer to territorial jurisdiction of the enforcing court which is established according to bailiff's office, as bailiff's jurisdiction is determined by reference to the jurisdiction of the Court of Appeal, which is to is conduct the enforcing, in accordance with the type of prosecution or enforcement. The criticized legal provision was adopted by the legislator within the framework of his/her competence, as established in the constitutional provisions of Article 126 para. (2) and Article 129, according to which "the courts' competence and the trial proceedings are stipulated solely by law" and "against the judge's decision, the interested parties and the Public Ministry may lodge a means of appeal, according to the legislation". The competent court is indeed established by law, but because of its general character - the district of the Court of Appeal - the text of Article 650 para. (1) of the Civil Procedure Code leaves a wide margin of appreciation to the creditor, who, indirectly, is the one determining the enforcing court by his/her choice of bailiff. However, the legislator does not hold any constitutional competence to leave the establishing of the competent court of law to pronounce judgment regarding a request addressed to justice, whatever the nature of the request, up to the parties.

As the Court also considered, by regulating the constitutional principles relating to the trial procedure, the legislator ensures both the right of the parties to follow a foreseeable procedural course and their right to reasonably adapt their conduct in accordance with the normative framework of the law, which represent indispensable guarantees of the right to a fair trial.

The Court found the provisions of Article 650 para. (1) of the Civil Procedure Code clearly not meeting the requirements of clarity, precision and predictability being thus, incompatible with the fundamental principle of observing the Constitution, its rule of law and laws, as stipulated under Article I para. (5) of the Constitution. As such, the Court can only conclude that the law submitted to the constitutionality review allows a subjective criterion of assessment on the part of one of the parties to the dispute, which is equivalent to the lack of precise determination of the competent enforcing authority, namely with debtor's impossibility of knowing of that court, in this case. It ensures that such a normative solution affects constitutional guarantees and implicitly, the conventional guarantees defining the right to a fair trial, guarantees mentioned in paragraph 17.

As a result, the Court determined the regulatory deficiencies highlighted in relation to the provisions of Article 650 para. (I) of the Civil Procedure Code to be likely to breach the provisions of Article 1 para. (5), Article 21 para. (3) and Article 126 para. (2) of the Constitution, as well as Article 6 of the Convention for the Protection of Human Rights and Fundamental Freedoms. It is therefore, legislator's task to expressly regulate the 
competent enforcing authority, precisely to give effect to the constitutional norm stipulated in Article 126 para. (2), in order to ensure the right to a fair trial, to adopt rules which, as shown, meet the criteria of precision, clarity and implicitly of predictability as required by the case law of the Constitutional Court and the European Court of Human Rights.

Thus, when corroborating the provisions of Article 650 with those of Article 651 of the Civil Procedure Code, if regarding the choice of bailiff, the margin of appreciation allowed by the legislator to the creditor is wider, offering him/her the possibility of choosing the bailiff from the district of the Court of Appeal, according to the nature of the goods which are to be the subject of the enforcing, and the obligations to be performed, as regards the establishing of the enforcing authority, it needs be circumscribed to clear and already established solutions within the legislation, such as the court to the district of which belongs the debtor's real estate, domicile or head office or the place where the enforcing procedure is to take place.

The Court upheld the unconstitutionality exception and found the provisions of Article 650 para. (1) of the Civil Procedure Code as unconstitutional.

Decision no. 348 of June 17, 2014 regarding the unconstitutionality exception of the provisions of Article 650 para. (1) and Article 713 para. (1) of the Civil Procedure Code, published in the Official Journal no. 529 of July 16, 2014

\section{Introducing the incumbent information on mediation}

\section{is unconstitutional}

The Court considered para. $\left(1^{2}\right)$ of Article 2 of the Law no. 192/2006 to have been introduced by Article I, pt. 2 of the Government Emergency Ordinance no. 90/2012 for the amendment and completion of Law no. 192/2006 regarding the mediation and regulation of the mediator profession, as well as for the modification of Article II of Law no. 115/2012 for the amendment and completion of Law no. 192/2006 regarding the mediation and regulation of the mediator profession, the emergency ordinance published in the Official Journal of Romania, Part I, no. 878 of December 21, 2012. Concurrently, the Court also considers that, according to the transitional provisions contained in Article VII of the Government Emergency Ordinance no. 4/2013 regarding the amendment of Law no. 76/2012 for the implementation of Law no. 134/2010 concerning the Civil Procedure Code, as well as for amending and supplementing certain related regulatory documents, amending Article III of the Government Emergency Ordinance no. 90/2012, the "Provisions of Article 2 para. $\left(1^{2}\right)$ of Law no. 192/2006 regarding the mediation and the regulation of the mediator profession, as subsequently amended and supplemented, concerning the sanction of inadmissibility of the writ of summons, apply solely to trials launched after August 1, 2013." Albeit Article 2 para. (1) 


\section{Unconstitutional legislative solutions enshrined by the Civil Procedure Code}

of Law no. 192/2006 concerns the obligation of the parties to participate in the briefings concerning the advantages of mediation, para. $\left(1^{2}\right)$ of the same article stipulates the sanction of inadmissibility of the writ of summons solely for the instance when the plaintiff has not fulfilled this duty. As such, it is not mandatory for the defendant to attend such a briefing, the only condition required for the plaintiff being fulfill being to contact a mediator who will notify the defendant, in accordance with Article 43 para. (1) of Law no. 192/2006, by sending him a written invitation, which can be send by any means ensuring the acknowledgement of receipt. The proof of attendance at the briefing concerning the advantages of mediation is made by an information certificate issued by the mediator who carried out the briefing. In case one of the parties refuses, in writing, to take part in the briefing, or does not answer to the invitation provided under Article 43 para. (1) or is not present at the date set for the briefing, a report shall be drafted, which shall be filed with the court file.

In this context, the Court considered that, as evidenced from the corroboration of Article 2 para. (1) with para. $\left(1^{2}\right)$ of Law no. 192/2006, in order to submit to the court a writ summons regarding the litigations in the content of Article 601 para. (1) letters a)-f) of the abovementioned law, the legislator has introduced a new obligation for the litigant, namely to previously contact a mediator which to inform him of the advantages of mediation. Under these circumstances, the Court finds that the introduction of mandatory disclosure in regard to the mediation is inconsistent with Article 21 of the Fundamental Law.

Although both national legislation, namely Law no. 192/2006 and the Civil Procedure Code [Article 227 para. (2) final thesis] as well as Directive 2008/52/EC of the European Parliament and of the Council enshrine mediation as a voluntary, alternative and informative procedure, Article 2 para. (1) of Law no. 192/2006 stipulates that it is incumbent for parties to participate in the briefing on the advantages of mediation, under the sanction of inadmissibility of the writ of summons, set up by para. $\left(1^{2}\right)$ of the same article. As such, although mediation is optional, howbeit, the mediation meeting is mandatory.

The Court also considered the criticized legal regulation, Article 2 para. (1) of the Law no. 192/2006, respectively, which compels the parties to proceed with the mediation briefing procedure, to rebut the irrefutable presumption "nemo censetur ignorare legem" (nobody is thought to be ignorant of the law). If the law, in this case Law no. 192/2006, with all its amendments, is published in the Official Journal of Romania, Part I, according to this apothegm, the citizen benefits from the presumption of knowledge of the law. Thus, a special procedure to inform about the content of such a law is not justified. Undoubtedly, this obligation imposed under any sanction, not only under that of the inadmissibility of the writ of summons, is contrary to the provisions of Article 21 of the Constitution, which stipulates that there isn't any law to restrict the exercise of free access to justice. The obligation to take part in the briefing regarding the advantages of mediation represents such a restriction of the free access to justice as it

CONSTITUTIONAL NEWS 
creates a filter for the exercise of this constitutional right, and by sanctioning the inadmissibility of the writ of summons, this right is not only restricted but even denied.

Since there may be situations where natural or legal persons would want the conflict to be settled exclusively in court, the Court has ascertained that by the criticized legal regulation the relevant individuals are not allowed to appreciate by themselves, whether they need this information. Free access to justice represents the ability of each person to appeal a court of law, in order to defend one's rights or to capitalize one's legitimate interests. Any limitation of this right, however insignificant it may be, must be thoroughly justified, the disadvantages it had created being examined to make sure they do not outweigh the possible advantages. Both in the case-law of the Constitutional Court and in the case-law of the European Court of Human Rights, it is shown that "its mere legal consecration, even on supreme level, through the Constitution, is not as such able to ensure its real effectiveness, as long as in practice, its performance is hampered. Consequently, the access to justice must therefore, be ensured in an effective and efficient manner" (see, for example, the Constitutional Court, Decision no. 670 of May 18, 2011, published in the Official Journal of Romania, Part I, no. 421 of June 16, 2011). In the context of the above, the Court found the obligation of taking part in the briefing regarding the advantages of mediation under the sanction of inadmissibility of the writ of summons imposed on the parties, natural or legal persons, as unconstitutional and contrary the provisions of Article 21 of the Constitution.

Considering Article 31 para. (2) of Law no. 47/1992 concerning the organization and functioning of the Constitutional Court, which stipulates that "If the exception is admitted, the Court will also rule on the constitutionality of other provisions of the contested document, which, clearly and necessarily, the above provisions cannot be dissociated from in the act of apprehension", the Court will extend its constitutionality control to the provisions of Article 2 para. $\left(1^{2}\right)$ of Law no. 192/2006, which establishes the sanction of the inadmissibility of the writ of summons in case of non-fulfilment of the obligation to attend the mediation briefing, obligation stipulated by Article 2 para. (1) of the same law, law criticized in this case.

Considering these arguments, the Court determined the provisions of Article 2 para. (1) and $\left(1^{2}\right)$ of Law no. 192/2006 regarding the mediation and organization of the mediator profession, with its subsequent amendments and completions, as unconstitutional, impinging on free access to justice.

Decision no. 266 of the May 7, 2014 of the Constitutional Court of Romania, regarding the objection of unconstitutionality of the provisions of Article 200 of the Civil Procedure Code, as well as those of Article 2 para. (1) and (1 $\left.{ }^{2}\right)$ and Article $60^{1}$ of Law no. 192/2006 regarding the mediation and regulation of the mediator profession, published in the Official Journal of Romania, Part I, no. 464, June 25, 2014 


\section{Unconstitutional legislative solutions enshrined by the Civil Procedure Code}

\section{The impossibility of the parties involved in a lawsuit to lodge of any}

means of appeal, determined by subjective monetary criterion, related to

the value of the object in case filed for judgment is unconstitutional

The Court held that, according to the criticized legal text - Article XVIII para. (2) of Law no. 2/2013 - judge's decisions given by judges regarding monetary claims, cannot be appealed because, according to Article 94 letter k) of the Civil Procedure Code, the money assessable claims fall within the jurisdiction of the court only if their value is less than 200.000 lei, except for money assessable claims expressly specified in Article 94 [e.g.: petitions for judicial partition that, regardless of value, fall within the jurisdiction of the court]. In what concerns Courts' rulings in lower court, the decisions in cases of requests regarding civilian navigation and harbor activity, labor disputes and social security, referring to expropriation, compensation claims for damages caused by judicial errors, as well as to other money assessable claims [those ranging from 200.000 to 1.000.000 lei] are not liable for second appeal. All the other court's rulings in lower court are susceptible to second appeal, unless the law expressly stipulates it otherwise. In conclusion, a court ruling regarding monetary assessable claims, in lower court shall not be subject to a second appeal under any circumstances; a judge's decision regarding monetary assessable claims, in lower court, shall not be subject to a second appeal when the claim value ranges between 200.000 and $\mathbf{1 . 0 0 0 . 0 0 0 ~ l e i . ~ T h e r e f o r e , ~}$ according to the criticized legal text, the second appeal is not only an extraordinary means of appeal, but it also becomes an exception, the rule established by the criticized provisions of the law being that of promotion of this means of appeal only in exceptional situations[monetary assessable claims amounting to more than 1.000 .000 lei]. The Court considers that, with regard to the possibility of filing for second appeal against judge's decision relating to monetary assessable claims, the legislator set out two criteria which rule out the second appeal against a judge's decision. Thus, the first criterion is represented by the matter which judgment was passed upon [matters referred to in Article 94 para. (1) letters a)-i), requests regarding civilian navigation and harbour activity, labour disputes and social security, referring to expropriation, compensation claims for damages caused by judicial errors, and the second criterion is represented by the value of the monetary assessable claims (amounting to more than 1.000.000 lei]. The Court will examine, within the limits of the act of apprehension, whether the legislator is competent as to impose a value threshold in what concerns the access to a means of appeal, even extraordinary, without reaching afore to a decision regarding the first criterion contained in Article XVIII para. (2) of Law no. 2/2013.

The Court also considers the second appeal as not representing an exceptional means of appeal but an extraordinary one. Classification of this means of appeal as extraordinary does not bind to it the decision typologies which may be subject to it, but aims only at the grounds for which it may be lodged. Hence, the designation of judge's decisions likely to be liable for a second appeal should take into consideration the 
nature of this procedural remedy and not other artificially created criteria which eliminate a multitude of individuals from this procedural remedy, despite them having an objective and rational justification. Also, the fact that a trial has two devolutive procedural stages (lower court and second appeal) does not automatically mean eo ipso the lack of the possibility to lodge a second appeal. In the current Civil Procedure Code, the purpose of the second appeal is to submit to the High Court of Cassation and Justice, along with the law stipulated exceptions, the examination of the conformity of the judgment under appeal, according to the applicable legislation. The High Court of Cassation and Justice has thus, jurisdiction to resolve the second appeal, with the law stipulated exceptions, as it is the cassation court function namely, to ensure the unitary interpretation and enforcement of the law by all Courts, function established by Article 126 para. (3) of the Constitution.

By the value threshold imposed by the criticized provisions of the law, the legislator explicitly acknowledges that only a part of the monetary assessable claims, i.e. those over 1.000.000 lei, can benefit from the compliance review, the others being excluded from this procedural guarantee. The criterion used by the legislator to access the second appeal lodged as a means of appeal - a value threshold of over 1.000 .000 lei - leads to the classification of claims addressed to courts in important ones, according to monetary value, and less important, that which represents an artificial and unjustified classification, since the difficulty of a problem of law cannot be assessed as based on the value of the litigation, but on its nature.

According to the regulations it adopts, the state must ensure equal protection of individuals' legitimate rights and interests, the idea that only those individuals having money related claims of a certain amount would benefit from the abovementioned protection being impossible to sustain. Otherwise, this would engender discrimination between citizens - as regards to the right to formulate a means of appeal - according to the value of the request submitted to the court of justice. This is the reason why even the extraordinary means of appeal must be accessible to all citizens, and why the limitations of access to them must explicitly result from their nature solely as well as from the reasons they can be stated for. The Court notices that the only justification for the legislator's setting of a value threshold for access to second appeal was the decongestion of the High Court of Cassation and Justice.

The Court ascertained that, since the legislator has regulated the means of a second appeal, the legislator must ensure citizens' equality before the law when lodging of this means of appeal, even if extraordinary. The legislator may introduce a different judicial handling of the second appeal by regulating certain situations which make it is impossible to state a second appeal, but this different judicial handling can not only be the expression of the legislator's exclusive assessment but it also must be objectively and reasonably justified, with the observance of the equality principle of the citizens before the law and public authorities, as established in Article 16 para. (I) of the Constitution. Consequently, the legislator is not entitled by constitution to block according to the value of the claim submitted to the court, the access to the second 


\section{Unconstitutional legislative solutions enshrined by the Civil Procedure Code}

appeal, as it positions the citizens, $a b$ initio, in a different situation, without an objective and reasonable justification. Considering these reasons, the Court ascertained that, by imposing a value threshold on the claim to file the second appeal, the legislator does not ensure the citizens the equality before the law in resorting to this extraordinary remedy at law, component of the right to a trial fair. Hence, the phrase "as well as in other monetary assessable claims amounting up to 1.000 .000 lei including" contained in Article XVIII para. (2) of the Law no. 2/2013 contravenes, to the provisions of Article 16 para. (1) of the Constitution, as well as to and those of Article 21 para. (3) of the Fundamental Law.

Furthermore, given the purpose of the second appeal, which, according to Article 483 para. (3) of the Civil Procedure Code is to submit the examination of the conformity of the contested decision according to the applicable rule of law, to the High Court of Cassation and Justice, the Court considers this purpose to be part of the mechanism made available to the Supreme Court in order to interpret and equally enforce the provisions of the legislation, as stipulated in Article 126 para. (3) of the Constitution, as well as of the granting the right to a fair trial, in the sense that the citizen must be confident that the law was correctly enforced on merits and that the public policy rules regarding the members of the court or its competence were observed, as other procedural rules judged as important, requirements with regards to the motivation of the decision or res judicata.

It is true the review for a uniform interpretation of the law represents another element of the mechanism of unitary interpretation and application of law, but it only applies in cases where there is uneven jurisprudence of a certain consistency ["The review for a uniform interpretation of the law is permissible only if the different resolution of the legal issues involved, by definitive court's ruling, annexed to the motion - Article 515 of the Civil Procedure Code, is proven]. Moreover, the review for a uniform interpretation of the law covers future situations, as it is not a direct remedy for the person in order to aid the restoration to the legal status quo in the given case submitted to the Court. Therefore, in the interest of unifying the jurisprudence, the High Court of Cassation and Justice not only acts to solution reviews for uniform interpretation of the laws, but also to quash decisions of judgments of lower courts not complying with the applicable legislation. As the second appeal is settled by the High Court of Cassation and Justice and, in certain cases specifically stipulated by law, by the hierarchically superior court to the one which has delivered the contested decision, the Court considers, in the case of second appeals falling within the jurisdiction of the High Court of Cassation and Justice, the criticized legal provisions as introducing a double measure regarding the assessment of the compliance of court decisions, by establishing, on the one hand, that the supreme court holds this role solely in certain situations and, on the other hand, only acts as such when the monetary assessable claims amount to a certain value. Therefore, in the case of second appeals falling under the jurisdiction of the High Court of Cassation and Justice, the phrase "as well as in other monetary

CONSTITUTIONAL NEWS 
assessable claims amounting up to 1.000.000 lei including", stipulated in Article XVIII para. (2) of Law no. 2/2013, also contravenes the provisions of Article 126 para. (3) of the Constitution.

Finally, the Court ascertained the effect of determining the unconstitutionality of the phrase "as well as in other monetary assessable claims amounting up to 1.000 .000 lei including", stipulated in Article XVIII para. (2) of the Law no. 2/2013, under prorogation circumstances from applicable provisions of Article 483 para. (2) of the Civil Procedure Code until January 1, 2019, to be such that starting with the publication date of this Decision in the Official Journal of Romania, the provisions of the Article XVIII para. (2) of Law no. 2/2013 are to be enforced in the sense that all judgments delivered subsequent to the publication of the present decision in the Official Journal of Romania are subject to second appeal, regarding the monetary assessable claims, except those exempted according to the criterion of legislation, expressly stipulated under Article XVIII para. (2) of Law no. 2/2013.

For the abovementioned reasons, the Court admits the unconstitutionality exception and ascertains the phrase "as well as in other monetary assessable claims amounting up to 1.000.000 lei including" under Article XVIII para. (2) of Law no. 2/2013 regarding certain measures designed to relieve the courts, as well as the preparation of the enforcement of Law no. 134/2010 concerning the Civil Procedure Code as unconstitutional.

Decision no. 369 of May 30, 2017 on the unconstitutionality exception of the phrase "as well as in other monetary assessable claims amounting up to 1.000 .000 lei including" under Article XVIII para. (2) of Law no. 2/2013 regarding certain measures designed to relieve the courts, as well as the preparation of the enforcement of Law no. 134/2010 regarding the Civil Procedure Code

See, mutatis mutandis, Decision no. 967 of November 20, 2012 on the unconstitutionality exception of the provisions of Article 1 point $I^{1}$ and Article 299 para. $\left(1^{1}\right)$ of the Civil Procedure Code, published in the Official Journal no. 853 of December 18, 2012

\section{Conferring the competence to decide on the compliance and merits of}

\section{the writ of execution, activity which used to be the attribute of the court of}

\section{law, to the bailiff is unconstitutional}

The lawsuit represents the activity performed by the court, parties, enforcing bodies and other persons or bodies involved in law courts' dispensing of justice in civil cases, with the purpose of achieving or establishing civil rights and interests submitted to the court and to foreclosure of judge's decisions and of other writs of execution. Thus, the lawsuit is divided into two phases: the trial and the foreclosure, the latter 


\section{Unconstitutional legislative solutions enshrined by the Civil Procedure Code}

taking place in case of judgments likely to be enforced by State's coercive force or of other writs of execution, insofar as the debtor fails to willingly perform one's duties.

The unitary character of the lawsuit requires the observance of guarantees characterizing the right to a fair trial both during the trial stage and during the foreclosure, the most important guarantee being the "right to a court" as stipulated in Article 21 of the Constitution and Article 6 of the Convention for the Protection of Human Rights and Fundamental Freedoms, i.e.: free access to an independent and impartial Court established by law, and control of acts performed during both phases of the trial by the Courts of law. In the same sense, the European Court of Human Rights which stated in its jurisprudence that "the right to a court as guaranteed under Article 6 para. (1) of the Convention would be insubstantial if the internal legal system of a contracting state would allow a final and binding judgment to remain ineffective at the expense of one party.

The carrying out of a sentence originating with any court must be considered as integrant to the "trial" under Article 6 "(Ruxandra Trading v. Romania, 2007, Homsby v. Greece, 1997). In accordance with the stated purpose, to adapt the foreclosure procedure to the requirements of Article 6 of the Convention for the Protection of Human Rights and Fundamental Freedoms and to remove the deficiencies noticed by the European Court of Human Rights in this matter which lead to the Romanian State to loose in a series of causes, the Romanian legislator proceeded with the adoption of certain amendments regarding the relevant rules in the field of foreclosure.

By removing judicial control over the commencement of foreclosure, the bailiff was given the power to decide on the compliance and merits of the foreclosure request, activity that constituted the attribute of the court of law. In other words, verifications performed prior to the amendment of Article $373^{1}$ of the Civil Procedure Code by the enforcing authority regarding the foreclosure approval (the existence and compliance of the writ of execution, the certain, liquid and exigible receivable, quality of the parties in the foreclosure proceedings), must be achieved, with respect to the new regulation of this legal text, by the bailiff who, according to Article $373^{1}$ para. (2) of the Civil Procedure Code, "is compelled to insist by all means permitted by law, for the full and quick fulfilment of the obligation stipulated in the writ of execution and for the observance of the provisions of the law, of the rights of the parties and of other interested persons".

Conferring such powers to bailiffs, who are not part of the judicial authority and whose activity, according to Article 4 of Law no. 188/2000 regarding the bailiffs, falls under the coordination and control of the Ministry of Justice, breaches both the constitutional provisions of Article 1 para. (4), according to which "The state is organized according to the principle of separation and balance of powers - legislative, executive and judicial - in a constitutional democracy", as well as those of Article 126 para. (I), according to which "Justice is passed through the High Court of Cassation and Justice and through the other courts established by the law". 
Also, allowing the representatives of an administrative service, which does not enjoy court's guarantees of independence and impartiality to evaluate a stage of the lawsuit breaches the right of the parties to a fair trial under Article 21 para. (3) of the Constitution and Article 6 of the Convention for the Protection of Human Rights and Fundamental Freedoms. And this all the more since the compliance of the commencement of the foreclosure proceedings affects all subsequent foreclosure proceedings and, therefore, all the parties involved in that procedure. The Court considers in this respect that the foreclosure must not be viewed unilaterally, only from the perspective of the creditor and his/her rights, but also from debtor's perspective, who must also be granted the guarantees specific to the right to a fair trial, by removing any abuse possibilities and possible bickering. Access to a court of law, by the possibility of challenging the foreclosure proceedings performed in violation of the law does not always constitute a sufficient remedy for the person against whom foreclosure proceedings were illegally commenced. A debtor's procedural guarantee is required for the prevention of any abuse in the exercising of pursuing creditor's right, and the judicial review of the commencement of the foreclosure procedure represented such an adequate and effective guarantee regarding the right to a fair trial of all parties involved in this procedure.

The removal of the judicial control of the commencement of foreclosure proceedings cannot be an answer to what the European Court of Human Rights has established i.e.: a component of the "adequate and sufficient legal arsenal" to which it refers. As shown, this amendment of the law breaches the separation of powers in state, the principles of justice and by doing so, the constitutional norms stipulated in Article 1 para. (3) enshrining the rule of law, and also encroaches the very spirit of that case-law. In this respect, the Court notices that Article $373^{1}$ of the Civil Procedure Code, in its new elaboration, determines the lack of real and effective control of the Court over the foreclosure proceedings, which results in the prolongation of the duration of the foreclosure through subsequent disputes arising from contestation of the writs of execution. On the other hand, a non-uniform and contradictory regulation of the foreclosure procedure is brought into existence. Thus, as consequence of the legislative amendment in question, the enforcing court no longer constitutes a file regarding the foreclosure, Law no. 188/2000 regarding the bailiffs further stipulates bailiff's obligation to submit copies of the writs of execution to the court, Article 50 para. (I) and (2) of the mentioned normative act stipulating that "Article $50-(1)$ in the performance of their duties the bailiffs shall write minutes, unless otherwise stipulated by law. (2) A copy of those written minutes shall remain with the bailiff and the other copies shall be submitted to the enforcing authority and to the interested parties, as the case may be". Such a lack of legislative correlation is likely to disturb the sound development of the foreclosure, thus creating malfunctions in its progress, thus having effects contrary to those established by the European Court of Human Rights. 
In conclusion, the Court found that the amendment to Article $373^{1}$ of the Civil Procedure Code, by the provisions of Article 1 point 13 of Law no. 459/2006, resulted in the abrogation of an important guarantee regarding the right to a fair trial of all parties involved in the foreclosure procedure by removal of courts of justice's control over the commencement of this procedure, this resulting the breaching of the stipulations of Article 1 para. (3) and (4), Article 21 para. (3) and Article 126 para. (I) with reference to Article 6 para. 1 of the Convention for the Protection of Human Rights and Fundamental Freedoms. In what concerns the provisions of Article 44 of the Constitution and those of Article 1 of Protocol no. 1 to the Convention for the Protection of Human Rights and Fundamental Freedoms, also invoked by the authors of the exception, in justifying the reasons, they are not relevant. For the abovementioned reasons, the Court admitted the unconstitutionality exception and ascertained the provisions of Article $373^{1}$ of the Civil Procedure Code, as amended by Article I point 13 of Law no. 459/2006, as unconstitutional.

Decision no. 458 of March 31, 2009 on the unconstitutionality exception of the provisions of Article $373^{1}$ of the Civil Procedure Code, as amended by Article 1, point 13 of Law no. 459/2006, published in the Official Journal no. 256 of April 17, 2009

See, mutatis mutandis, and Decision no. 895 of December 17, 2015 on unconstitutionality exception of the provisions of Article 641 and Article 666 of the Civil Procedure Code, published in the Official Journal no. 84 of February 4, 2016

10. The sanctioning by absolute nullity of the filing of a second appeal (or of the appeal) in a court other than the one the decision of which is being

\section{challenged is unconstitutional}

The object of the unconstitutionality exception is represented by the provisions of Article 302 of the Civil Procedure Code, which read as follows: "The second appeal shall be submitted with the court the decision of which is being challenged, under the penalty of nullity".

By examining the unconstitutionality exception, the Constitutional Court found the unconstitutionality exception well founded. In accordance with the provisions of Article 129 and Article 126 para. (2) of the Romanian Constitution, the exercise of legal remedies against judge's decision and the trial procedure are stipulated in the legislation. It ensues from these constitutional provisions that the legislator benefits from the freedom to determine the cases and conditions under which the interested parties and the Public Ministry may exercise the remedies at law. The Court also considers the freedom of the legislator to determine the conditions for the second appeal while the trial proceedings as limited, and the limits of freedom of regulation

CONSTITUTIONAL NEWS 
being determined in these cases too by the compulsoriness to observe the rules and principles regarding the fundamental rights and freedoms as well as other principles established under the Fundamental Law and under the international judicial acts which Romania is a party of.

In this respect, the Court considered that, according to Article 21 para. (1) and (2) of the Constitution of Romania, any person may appeal to justice for the protection of one's rights, freedoms and legitimate interests, and no law can hinder the exercise of this right. In regulating the access to justice, the legislator benefits from the possibility to impose certain formal conditions, pertaining to the nature and requirements to dispensing justice, however, without these conditionings bringing prejudice to the essence of the right or to render it ineffective.

In the light of these considerations, the Constitutional Court found the provision under Article 302 of the Civil Procedure Code, whereby the filing of a second appeal in a court, other than that the judgment of which is being challenged, is sanctioned with absolute nullity, to be an unacceptable rigid formalism, liable to seriously affect the effectiveness of the lodging of a means of appeal and to unduly restrict free access to justice. The sanction is all the more unjustified since the error of filing a second appeal with the court itself or with a court other than that the judgment of which is being challenged, is ascribable not only to the appellant but also to the magistrate or clerk receiving the wrongly filed notice of appeal, despite having the option of guiding the concerned individual as stipulated by the law.

For the purpose of the above mentioned, the Court considered the application of constitutional principles with regard to the free access to justice and the lodging of a means of appeal to require that all misappropriated claims be submitted to the relevant jurisdiction to be settled. On the other hand, according to the Civil Procedure Code system, the second appeal is regarded as an extraordinary remedy, that is, as an ultimate level of jurisdiction when the parties to the dispute can defend their subjective rights by removing the effects of the judgments given in unduly circumstances under Article 304 of the Civil Procedure Code. Establishing the penalty of nullity for nonfulfilment of the requirement stipulated in the examined text - most of the time out of error, ignorance or of other reasons not imputable to the appellant - strips him/her without reasonable justification, of the possibility of examining, by way of second appeal, his/her well-founded claims regarding the allegedly abusive, erroneous manner the disputes in which he/she is party of, were settled by the challenged decision.

For the outlined reasons, the Court accepted the unconstitutionality exception and ascertains the provisions of Article 340 of the Civil Procedure Code, namely the part stating "under penalty of nullity", as unconstitutional.

Decision no. 737 of June 24, 2008 on the unconstitutionality exception regarding the provisions of Article 302 of the Civil Procedure Code, published in the Official Journal no. 562 of July 25, 2008

CONSTITUTIONAL LAW REVIEW 


\section{Unconstitutional legislative solutions enshrined by the Civil Procedure Code}

See, mutatis mutandis, and Decision no. 303 of March 3, 2009 on the unconstitutionality exception regarding the provisions of Article 288, 2 of the Civil Procedure Code, published in the Official Journal no. 239 of April 10, 2009

\section{Prohibition of the use of interrogation to prove the grounds for divorce is unconstitutional}

The object of the unconstitutionality exception is represented by the provisions of Article 612 para. (6) of the Civil Procedure Code, which stipulate the following: "Interrogation request to prove the reasons for divorce is not allowed".

The Court took notice of the texts governing the divorce procedure as providing two distinct situations concerning the parties that can file for divorce. In the first case, the petition for divorce is filed by one of the spouses, while in the second case both spouses file for divorce. In what concerns the first situation, it is obvious from the examination of the legal text by the Compliance office that the performance of the interrogation evidence cannot be required by the plaintiff spouse in order to prove the grounds for divorce, but may be demanded by the defendant spouse to challenge those grounds. The Court ascertains in this situation, the criticized legal text to affect the provisions of Article 16 para. (I) of the Fundamental Law on Citizens' Equality before the Law and Public Authorities. Thus, the Constitutional Court has consistently laid out within its case-law, in keeping with the case-law of the European Court of Human Rights (Marckx v. Belgium, 1979) that "the violation of the principle of equality and nondiscrimination exists when equal cases are treated differently without any objective and reasonable motivation, or if there is a disproportion between the aim pursued by unequal treatment and the used means" (Decision of the Constitutional Court no. 100 of March 9, 2004, published in the Official Journal of Romania, Part I, no. 261 of March 24, 2004). As such, the Court ascertains that there is no objective and reasonable justification to prevent plaintiff spouse's access to the examination of important evidence during the divorce proceedings, to the interrogation, respectively. Furthermore, according to Article 5 of Protocol no. 7 additional to the Convention for the Protection of Human Rights and Fundamental Freedoms, "spouses enjoy equal rights and responsibilities of civilian nature, between themselves and in their relation with their children in what concerns the marriage, during the marriage and upon its dissolution. This article does not prevent the States from taking the necessary measures in children's interest". In applying this article, the European Court of Human Rights ruled, in essence, in the case of losub Caras v. Romania (2006), the Article 5 of Protocol no. 7 as imposing a positive obligation on States, namely to provide the appropriate legal framework, according to which the spouses have equal rights and obligations. The Court noted the criticized legal provisions to also prejudice the constitutional provisions

CONSTITUTIONAL NEWS 
of Article 21 para. (3) regarding the right to a fair trial and the settlement of cases within a reasonable amount of time, as well as those of Article 6, regarding the right to a fair trial as stipulated in the Convention for the Protection of Human Rights and Fundamental Freedoms, in the light of Article 20 of the Constitution, concerning international human rights treaties. Thus, the Court ascertains the criticized law to prejudice an essential element of the fair trial, namely the principle of equality of arms. With regard to this principle, the European Court of Human Rights ruled in Dombo Beheer BV v. The Netherlands (1993) that each party in such a lawsuit must benefit from a reasonable chance to state one's case before the court, including in what regards the evidence, under conditions that do not significantly disadvantage that party against the antagonist. However, the criticized legal provision, according to which the plaintiff spouse cannot request the administration of the interrogation test, creates a significant disadvantage for him/her.

Concerning the second situation, in which both spouses file for divorce, the Court noted that, according to the criticized law, none of them is entitled to request the administration of the interrogation test to demonstrate the grounds for the divorce. Each of them, however, as defendant, may use the interrogation test to counter the other spouse's grounds. Such a legal circumstance in the procedure for evidence examination is clearly confusing and contradictory. Under these circumstances, the Court considered the provisions of Article 612 para. (6) of the Civil Procedure Code to infringe the right to a fair trial, governed by Article 21 para. (3) of the Constitution and Article 6 of the Convention for the Protection of Human Rights and fundamental freedoms as it prevents the carrying out of the interrogation in proving the grounds for divorce. The interrogation represents an essential proof regarding the personal actions of spouses, which can lead to the clarification of the case.

The specificity of marriage relationships makes it difficult in certain cases, to prove the grounds for divorce, so that the Court considers it necessary to administer all the evidence that might provide the court with enough grounds as to settle the case. Finally, the Court considers that the reason regarding the prejudice to personal life which could be invoked in justifying the maintenance of the current legal text is not to be taken into account, as the issue is the admissibility of interrogation in principle and not of the questions which may be asked on that occasion, questions that are subject to the censorship of the court in the exercise of its active role. The court can also invoke Article 121 of the Civil Procedure Code, and rule the debates to be held in secret, in case the public debate would lead to the prejudice of the parties.

For the reasons set out, the Court granted the unconstitutionality exception and ascertained the provisions of Article 612 para. (6) of the Civil Procedure Code as unconstitutional.

Decision no. 969 of October 30, 2007 on the unconstitutionality exception regarding the provisions of Article 612 para. (6) of the Civil Procedure Code, published in the Official Journal no. 816 of November 29, 2007

CONSTITUTIONAL LAW REVIEW 
12. It is unconstitutional the sanctioning by absolute nullity the omission to specify in the second appeal the "name, domicile or residence of the parties or, for legal persons, their name and headquarters as well as, where appropriate, the registration number with the Trade Register or with the Registry for Legal Persons, the sole registration code or, as the case may be, the fiscal code and the bank account", as well as - if the appellant lives abroad - "the chosen address in Romania, where all communications regarding the lawsuit are to be carried out" thus, of certain elements which neither are indispensable for the purposes of the judgment, nor are mentioned in the operative part of the challenged judgment

The Constitutional Court ascertained the provisions of Article $302^{1}$ para. (1) letter a) of the Civil Procedure Code, under which the omission to specify in the second appeal the name, domicile or residence of the parties or, for legal persons, their name and headquarters as well as, where appropriate, the registration number with the trade register or with the Registry for Legal Persons, the sole registration code or, as the case may be, the fiscal code and the bank account", as well as - if the appellant lives abroad "the chosen address in Romania, where all communications regarding the lawsuit are to be made" is sanctioned by absolute nullity, to appear as an unacceptably rigid formalism that could seriously prejudice the effectiveness of the means of appeal and unduly restrict the free access to justice.

In this context, the Court noted most of the elements set out in the challenged legal text, namely the address or residence of the parties or, for legal persons, their name and headquarters as well as, where appropriate, the registration number with the Trade Register or with the Registry for Legal Persons, the sole registration code or, as the case may be, the fiscal code and the bank account, as well as - if the appellant lives abroad - the chosen address in Romania, where all communications regarding the lawsuit are to be made, to be in full, in the case file for which judgment was given, judgment which represent the subject of the means of appeal, and that they are not indispensable for the purpose of identifying the relevant judgment and are not even mentioned in the operative part of the challenged judgment. On the other hand, according to the system of the Civil Procedure Code, the second appeal is conceived as an extraordinary means of appeal, that is to say, as the ultimate level of jurisdiction in which the parties to the dispute may defend their subjective rights by eliminating the effects of decisions given in the circumstances of the 10 cases of illegality as stipulated under Article 304 of the Civil Procedure Code. However, imposing a nullity penalty for non-fulfilment of these formal requirements within the second appeal itself, without 
any possibility of omission remedy, deprives the appellant, without reasonable justification, from examining, by way of second appeal, his/her allegations based on the erroneous, possibly abusive, manner in which the dispute he/she is part of was settled by the challenged judgment.

Considering these effects of the enforcement of the provisions of Article $302^{1}$ para. (1) letter a) of the Civil Procedure Code, the Court ascertained by sanctioning the nullity it institutes, the contested legal text as contravening both the provisions of Article 21 as well as those of Article 129 and Article 24 para. (I) of the Constitution. The opinion communicated by the Government of Romania that the nullity stipulated under Article $302^{1}$ para. (1) letter a) of the Civil Procedure Code could be eliminated by applying the provisions of Article 316 of the same code, cannot be accepted, in order to establish the constitutionality of the contested legal text, given that the cited law stipulates that procedural provisions regarding the proceedings during appeal provisions under which the omissions referred to in the contested legal text are not sanctioned by nullity - are also applied by the Court of Appeal, insofar as they are not contrary to those contained in the chapter regarding the second appeal. However, the specificity of the provisions of the contested legal text in relation to the provisions of Article 287 of the Civil Procedure Code, which governs the content and validity conditions of the request for appeal, is obvious. The Court ascertains the contested legal text as unconstitutional with regard to the absolute nullity sanctioning of the omission to specify in the request for a second appeal the name, domicile or residence of the parties or, for legal persons, their name and headquarters as well as, where appropriate, the registration number with the trade register or with the Registry for Legal Persons, the sole registration code or, as the case may be, the fiscal code and the bank account", as well as - if the appellant lives abroad - "the chosen address in Romania, where all communications regarding the lawsuit are to be carried out".

For the reasons set out, the Court accepted the unconstitutionality exception of the provisions of Article $302^{1}$ para. (1) letter a) of the Civil Procedure Code and ascertains the contested legal text as unconstitutional with regard to the absolute nullity sanctioning of the omission to specify in the request for second appeal the name, domicile or residence of the parties or, for legal persons, their name and headquarters as well as, where appropriate, the registration number with the trade register or with the Registry for Legal Persons, the sole registration code or, as the case may be, the fiscal code and the bank account", as well as - if the appellant lives abroad - "the chosen address in Romania, where all communications regarding the lawsuit are to be made."

Decision no. 176 of March 24, 2005 on the unconstitutionality exception regarding the provisions of Article $302^{1}$ para. (1) letter a) of the Civil Procedure Code, published in the Official Journal no. 356 of April 27, 2005

CONSTITUTIONAL LAW REVIEW 


\section{Unconstitutional legislative solutions enshrined by the Civil Procedure Code}

13. Cancelling or, as the case may be, rejection of the second appeal

for non-fulfilment of formal requirements or for faulty or inadequate

reasoning of the second appeal, without summons to court

of the parties is unconstitutional

The annulment or, as the case may be, the dismissal of the second appeal under the conditions stipulated under Article 308 para. (4) of the Civil Procedure Code, i.e.: that is for failure to comply with the formal requirements or for faulty or inadequate reasoning of the second appeal, without summons to court of the parties and thus, without allowing the appellant the opportunity to provide, directly or through a lawyer, the judges with the necessary explanations concerning the relevant admissibility conditions, constitutes a clear violation of the principle of free access to justice and of the right of defense as stipulated under Articles 21 and 24 para. (I) and (2) of the republished Constitution of Romania. To this end, the expression "formal requirements" is considered to include the stipulations of Article $302^{1}$ of the Civil Procedure Code, including the name, domicile or residence of the parties, the specification of the judgment to be challenged, the reasons which the second appeal is based on and the signature of the party who filed the second appeal. By considering these statements, expressing the principle of free access to justice, the legislator provided in Article 316 of the Civil Procedure Code, corroborated with Article 287 para. (2) of the same code both texts being valid - the possibility of fulfilling the abovementioned requirements until the first hearing day and the lack of signature, under the conditions stipulated under Article 133 para. (2) of the Civil Procedure Code, i.e.: throughout the course of the trial. Examination of the admissibility of second appeal without summons to court of the party who resorted to the means of appeal makes the reparation of the formal flaws referring to in Article 308, $\S 4$ of the Civil Procedure Code impossible. Annulment or rejection of the second appeal under these circumstances appears as an unjustified restriction of the lodging of this means of appeal and thus, of the free access to justice. In what concerns the failure to invoke the reasons for appealing and their development within the limits of the cases provided under Article 304 of the Civil Procedure Code, it should be noted that when the subject of a second appeal is represented by a decision which, according to the law, cannot be appealed against, Article $304^{1}$ of the same code, leaves to the Court of Appeal the possibility to examine all aspects of the case, that is to say beyond the said limits. In this case, the second appeal constitutes a devolutive means of appeal, in which, as with the second appeal, the Court of Appeal itself judges the cause both in terms of legality and its merits, without limiting to judge only the lower court's decision, solely for the cassation reasons stipulated under Article 304 of the Civil Procedure Code. The refusal or, as the case may be, the annulment of the second appeal in this case, under the challenged legal provision, without summons to court of the appellant, represents a clear violation of appellant's right to defense by

CONSTITUTIONAL NEWS 
invoking, in support of the appeal, certain reasons for the groundlessness of the decision, result of erroneous appreciation of the examined evidence.

The Court has also ascertained, as in the case of the other grounds for cassation under Article 304 of the Civil Procedure Code, in relation to the principles of the Fundamental Law, as impossible to justify the annulment or, as the case may be, the dismissal of the second appeal without summons to court of the party having appealed to the remedy at law, in the event valid reason for cassation exists, but the appellant has indicated or developed it erroneously. In order to avoid such a situation, Article 306 para. (3) of the Civil Procedure Code stipulates that the erroneous indication of the grounds of appeal does not entail the nullity of the appeal if their development makes it possible for them to be classified under one of the reasons stipulated under Article 304 . In the same sense, Article 306 para. (2) stipulates that the grounds of public order can be invoked ex officio by the court of appeal, which is, however, compelled to have the parties debate them. However, it is obvious that the mentioned legal provisions cannot be applied by the panel deciding on the admissibility, in principle, of the second appeal, without summons to court of the parties, which leads, in this respect as well, to the criticized legal text to be contrary to the provisions of Article 24 para. (I) and (2) of the republished Constitution.

For the reasons set out, the Court accepted the unconstitutionality exception regarding the stipulations of Article 308 para. (4) of the Civil Procedure Code, as amended and supplemented by the Government Emergency Ordinance no. 58/2003, and ascertains this legal text as unconstitutional, namely the part expressed by the phrase "without summons to court of the parties".

Decision no. 194 of April 27, 2004 on the unconstitutionality exception of the provisions of Article 308 para. (4) of the Civil Procedure Code, amended and supplemented by the Government Emergency Ordinance no. 58/2003, published in the Official Journal no. 523 of June 10, 2004

14. The regulation of the deadline for the lodging of the right to the second appeal since the decision of the judge, when it was dispensed without summons to court of the parties is unconstitutional

The unconstitutionality exception concerned Article 22 para. (5) of the Civil Procedure Code, which states: "In order for the competent court to rule the conflict, its members shall decide in the council chamber, without summons to court of the parties, with right to appeal within 5 days of pronouncement".

By examining the case, the Constitutional Court ascertained the unconstitutionality exception as well founded and that a part under Article 22 para. (5) of the Civil Procedure Code is unconstitutional, namely the part stipulating that the deadline for the 
Unconstitutional legislative solutions enshrined by the Civil Procedure Code

lodging of the right of second appeal elapse from the passing of the judgment comprising the competence controller. According to the criticized article, the competent court to judge the conflict of jurisdiction decides, in the council chamber, without summons to court of the parties. The fact of not summoning to court of the parties for the judging of the conflict of jurisdiction deprives them of the opportunity of knowing the solution and the date of its adjudication, so that the regulating of the use of the right of appeal until a certain deadline from the judgment delivery, most often triggers the impossibility of exercising the right. Thus, the possibility of actually exercising the constitutional right to defense as stipulated under Article 24, namely by using the means of appeal, according to the right provided under Article 128 of the Constitution is eliminated. Given the existence of the two exceptions to the common law provided for in Article 22 para. (5) of the Civil Procedure Code - namely, failure of summoning to court of the parties and the expiration of the deadline for the filing a second appeal the actual lodging of the right of second appeal and thereby of the right to defense, can only be achieved by applying the general rule stipulated in Article 301 of the Code, according to which the deadline for the filing of a second appeal elapses with the date of notification of the challenged judgment. For the abovementioned reasons, the Court admitted the unconstitutionality exception and ascertained that the provision of Article 22 para. (5) of the Civil Procedure Code, according to which the deadline for the exercising of the right of a second appeal elapses since the ruling containing the competence controller as unconstitutional.

Decision no. 11 of February 9, 1999 on the unconstitutionality exception under Article 22 para. (5) of the Civil Procedure Code, published in the Official Journal no. 136 of April 1, 1999

15. Suspending the enforcement of Court's final decision by the prosecutor s unconstitutional

The Court unanimously accepted the unconstitutionality exception regarding the provisions of Article $330^{1}$ para. (1) of the Civil Procedure Code, which states that: "The Prosecutor General may temporary order, the suspension the enforcement of Court's final decision before submitting the second appeal for annulment".

In order to reach this solution, basically it was considered that these provisions affect the principle of separation of powers in state, a principle which, although not explicitly enshrined, could be inferred from all constitutional regulations and, in particular, those referring to the specification of the role of public authorities and the relations between them. This is because, according to the provisions of Article 131 para. (1) of the Constitution, the prosecutors carry out their activity "under the 
authority of the Minister of Justice", an essentially executive body, thus, being agents of the executive authority themselves. Thus, prosecutors could order the suspension of the enforcement of a Court's final decision only by violating the principle of separation of powers in state. In order to support the solution, the decision of the Plenum of the Constitutional Court no. 6/1992 was invoked, whereby, it was decided in another context, that a legal provision suspending the trial or the enforcement of Court's final decisions regarding certain determined causes is unconstitutional, being pointed out that since neither the legislative authority is entitled to order the suspension of the enforcement of judge's decisions relating to certain determined causes, all the more is such measure impossible to be adopted by another authority.

Decision no. $73^{3}$ of June 4, 1996 regarding the exception of unconstitutionality of the provisions of Article 330, Article $330^{1}$, Article $330^{2}$, Article $330^{3}$ and Article $330^{4}$ of the Code of Civil Procedure, published in the Official Journal no. 255 of October 22, 1996

See also Decision no. 96 of September 24, 1996 on the resolution of appeals against the Decision of the Constitutional Court no. 73 of 4 June 1996, published in the Official Journal no. 251 of October 17, 1996, whereby the Court partially accepted the unconstitutionality exception on Article $330^{1}$ of the Civil Procedure Code and ascertains its provisions as unconstitutional insofar as they apply to judgments rendered prior to July 26, 1993, the date of entry into force of Law no. 59/1993

16. Restricting prosecutor's right to participate in any civil proceeding during any stage, if he deems it necessary to defend the rule of law or the rights and freedoms of citizens is unconstitutional. This cannot however imply neither the participation in all civil cases nor the transfer of competences exceeding his constitutional role, for example in what concerns the foreclosure

The constituent legislator meant to transform the Public Ministry into a representative of the social, general and public interest, the role of which would be to survey the enforcement of the law and to defend citizens' rights and freedoms, without distinguishing between criminal trial and lawsuit. One of the concrete forms by which the Public Ministry is able to accomplish this is to participate in the proceedings during any of their stages and to draw conclusions consonant with the objectives set by the Constitution. The constituent legislator meant to provide the prosecutor with a certain position in representing the general interests of society, since he/she has set the

\footnotetext{
${ }^{3}$ Definitive as a result of Decision no. 96 of 24 September 1996.
}

CONSTITUTIONAL LAW REVIEW 


\section{Unconstitutional legislative solutions enshrined by the Civil Procedure Code}

provisions concerning the Public Ministry in the chapter on the "judicial authority" and there is not any organic or ordinary law that can deviate from constitutional text. Court's role in solving the case it was submitted, as well as the judges' independence and their submission only to the law, are not affected by prosecutor's participation in the lawsuit and by him/her drawing conclusions. The prosecutor is not the opponent of the court or of any of the parties; he intervenes during the lawsuit to ensure the compliance with the law. The purpose of constitutional text, referring to the defense of citizens' rights and freedoms, is not to turn the prosecutor into one of the party's lawyer but to ensure that the law is observed during trials that call such rights and freedoms into question. Although a case of private lawsuit, it is indisputable that there are general interests that must be defended in this area and for the judicial activity the Constitution designated this defensive role to a prosecutor. On the other hand, the principle of availability, which governs the lawsuits, continues to function because, by prosecutor's participation in the lawsuit, the parties are not prevented from manifesting their right regarding the act of disposing, according to the law. In relation to these considerations, the Constitutional Court is to ascertain Article 45 para. (1) of the Civil Procedure Code as unconstitutional with regard to the restriction of the prosecutor's right to participate in any lawsuit during any of the stages of the proceedings and, as such, the provisions of Article 130 para. (1) of the Constitution are to apply directly in regard to this duty. Thus, unless the prosecutor is required to participate in lawsuit according to the law, he/she may participate in the resolution of any lawsuit at any stage if he/she deems it necessary for the defense of the rule of law or of citizens' rights and freedoms.

For these reasons, the Court admitted the unconstitutionality exception and ascertained Article 45 para. (1) of the Civil Procedure Code as unconstitutional in what concerns the limiting of prosecutor's right to participate only in proceedings with regard to the "protection of the rights and legitimate interests of minors and persons subject to prohibitory interdict, as well as in other cases stipulated by the law" and, as regards this attribution, Article 130 para. (1) of the Constitution is to apply directly.

Decision no. 1 of January 4, 1995, published in the Official Journal of Romania no. 66 of April 11, 1995

According to the provisions of Article 132 para. (1) of the Constitution of Romania: "Prosecutors carry out their activity according to the principle of legality, impartiality and hierarchical control under the authority of the Ministry of Justice". Moreover, according to Article 62 para. (4) of Law no. 304/2004 regarding the judicial organization, republished in the Official Journal of Romania, Part I, no. 827 of September 13, 2005: "The Prosecutors' offices are independent in the relations with the Courts of law, as well as with other public authorities". It is true that during judicial activity, the Public Ministry represents the general interests of the society and defends the rule of law and citizens'

CONSTITUTIONAL NEWS 
rights and freedoms, but the criticized legal provisions transfer within prosecutor's responsibility the attributions in the field of foreclosure by taking, upon bailiff's request, certain concrete steps leading to the establishment of subordinate relations between the bailiff on the one hand and the prosecutor on the other. The Court considers the legislator to be entitled to assign certain powers to the prosecutor during this stage of the lawsuit, although the duties of the Public Ministry are primarily exercised in the field of criminal judicial activity (see to that effect, Decision no. 71 of March 5, 2002, published in the Official Journal of Romania, Part I, no. 309 of May 10, 2002). This must be done according to the constitutional provisions. It is certain the legislator benefits from the possibility of setting up various mechanisms demanding the involvement of the criminal investigation bodies, as the Public Ministry could be submitted a request concerning the necessary information during the foreclosure phase. These mechanisms should, however, provide the prosecutor's ability to assess the need for his/her intervention, in relation to the general interests of society, the need to defend the rule of law and citizens' rights and freedoms [according to Article 131 para. (1) of the Constitution]. Regardless of the legislator's future legislative option, he/she has to take into account, beside the mentioned constitutional provisions also the jurisprudence of the European Court of Human Rights, such as the Decision of January 15, 2009, pronounced in the case Menchinskaya $v$. Russia, paragraph 35.

Thus, according to this jurisprudence, the prosecutor's intervention in the lawsuit may be justified by certain circumstances, such as the protection of vulnerable groups children, people with disabilities - who are supposed to be unable to defend their own interests, when many a citizen are affected by certain facts or when state's interests must be protected. Moreover, the Constitutional Court has also ruled in the same sense when it considered the lawsuit by nature to be a process in which private interests are confronted. Therefore, as a consequence, the role of the Public Ministry is objectively reduced (see to that effect, Decision no. 71 of March 5, 2002, published in the Official Journal of Romania, Part I, no. 309 of May 10, 2002). This duty of the legislator stems from the fact that Romania has become member of the Convention for the Protection of Human Rights and Fundamental Freedoms following its ratification by Law no. 30/1994, published in the Official Journal of Romania, Part I, no. 135 of May 31, 1994, assuming thus, the obligation to observe the provisions of this Convention, as well as the interpretation given by the European Court of Human Rights to the abovementioned Convention, within the limits provided by this Convention, in accordance with the provisions of Article 46, according to which "the High Contracting Parties undertake it to comply with the Court's final judgments in the disputes which they are parties to" (see also, in this respect, the Constitutional Court's Decision no. 233 of February 15, 2011, published in the Official Journal of Romania, Part I, no. 340 of May 17, 2011). 
Unconstitutional legislative solutions enshrined by the Civil Procedure Code

Hence, the Court ascertained these mechanisms to be likely to intervene solely in strictly determined cases and only after the bailiff has exhausted all legal means provided by the law, in order to enforce the writs of execution (e.g.:, the bailiff has at his disposal the legal instruments provided under Article 659 para. (1) in conjunction with Article 187 para. (1) point 2 letter f) and Article 189 of the Civil Procedure Code].

Decision no. 473 of November 21, 2013 regarding the unconstitutionality exception of the provisions of Article 659 para. (3) of the Civil Procedure Code was published in the Official Journal, Part I, no. 30 of January 15, 2014 